\title{
Outside Offers and the Gender Pay Gap: Empirical Evidence from the UK Academic Labour Market*
}

\author{
Alison L Booth \\ University of Essex and the Australian National University \\ Jeff Frank \\ Royal Holloway College, University of London \\ David Blackaby \\ University of Wales, Swansea
}

revised May 2002

\begin{abstract}
* The data set for this project derives from a questionnaire undertaken by the Royal Economic Society Working Party on the Representation of Ethnic and Other Minorities in the Economics Profession. We benefited from discussions at the Warwick University Summer School in Labour Economics, from presentations at the ESRC Future of Work programme seminars, at the University of California Berkeley and the Australian National University, and at the SOLE meetings in Baltimore in 2002. We acknowledge very useful suggestions from Ron Ehrenberg, Daniel Hammermesh, and Walter Oi. Booth and Frank are grateful to the ESRC for financial support under 'The Future of Work: Flexible Employment, Part-time Work and Career Development in Britain', award number L212 252007.
\end{abstract}

\begin{abstract}
Using a unique data source on academic economist labour market experiences, we explore gender, pay and promotions. In addition to earnings and productivity measures, we have information on outside offers and perceptions of discrimination. In contrast to the existing literature, we find both a gender promotions gap and a within-rank gender pay gap. A driving factor may be the role of outside offers: men receive more outside offers than women of comparable characteristics, and gain higher pay increases in response to outside offers. This may arise due to discrimination, and we find that perceptions of discrimination and also outside job applications correlate with an individual receiving earnings below that expected, given their characteristics.
\end{abstract}

Keywords: gender, promotions, earnings, discrimination

JEL Classification Numbers: J16, J33, J71

Corresponding author: Jeff Frank, 69 Roupell Street, Waterloo London SE1 8SS

England, j.frank@rhul.ac.uk, 44-208-265-4203 


\section{Outside Offers and the Gender Pay Gap}

'In contrast to junior women, many tenured women faculty feel marginalized and excluded from a significant role in their departments. Marginalization increases as women progress through their careers at MIT. Examination of data revealed that marginalization was often accompanied by differences in salary, space, awards, resources, and response to outside offers between men and women faculty with women receiving less despite professional accomplishments equal to those of their male colleagues.'

A Study on the Status of Women Faculty in Science at MIT, 1999

A number of recent studies have investigated gender, promotions and pay in the academic labour market. McDowell, Singell and Ziliak (1999, 2001) look at US academic economists and find that women have been disadvantaged in promotions, although the effect seems to be diminishing over time. Ginther and Hayes $(1999,2000)$ examine salaries of US humanities academics and find a gender gap, although they conclude that this is explained by rank rather than within-rank differentials. Ward (2000) looks at Scottish academic salaries (across disciplines) and comes to a similar conclusion. In this study, we use data on UK academic economists, collected by the Royal Economic Society in 1999 , to examine gender differentials. ${ }^{1}$

Gender differentials in academic pay and promotions are of interest to us directly as academic economists. However, the academic labour market is an excellent source for more general insights on discrimination. There are well-defined ranks so it is clear when an individual has been promoted. In other organisations, considerable effort has to be made to infer the actual ranking of different jobs [see, for example, Baker, Gibbs and Holmstrom (1994)]. Some aspects of productivity - such as publications - are readily 
measurable. With limited exceptions [such as Lazear's (2000) study of windshield installations], the actual measurement of productivity of individuals in either the commercial or public sectors is extremely difficult, particularly for managerial workers most likely to have significant promotion opportunities. Most importantly, our sample of academic economists was willing to provide information - including information about outside offers and job applications - which is unavailable in the personnel records of a commercial enterprise. This unique information allows us to understand some of the mechanisms that sustain gender gaps in pay and promotions. We also have information on perceptions of discrimination, and can examine whether there are objective factors determining an individual's perceptions of whether she has suffered discrimination, and how these perceptions affect her behaviour in the labour market.

We confirm the results in the literature that there is a significant gender promotions gap. In contrast to Ginther and Hayes (2000) and Ward (2000), we also find that there is a significant within-rank pay gap. We find important gender differences in outside offers and the earnings effect of outside offers. For given productivity, individual and workplace characteristics, men receive more outside offers than women. For men, but not for women, more outside offers are associated with higher earnings. These results are consistent with the small sample MIT study, from which we quote at the start of this paper, and suggest that the determination of salaries by outside offers plays an important role in sustaining the gender gap. We find that academics who perceive discrimination have an objective basis for their beliefs, and behave in a way consistent with their perceptions. Those who are under-paid relative to their observable characteristics are

\footnotetext{
${ }^{1}$ The data was collected by the Working Party on the Representation of Ethnic and Other Minorities in the Economics Profession. The Working Party agreed that the data would be made available for replication
} 
more likely to report that they have suffered from discrimination. We also find that these academics are more likely to apply for outside jobs.

Our results are consistent with the 'loyal servant' hypothesis that women are believed to be less likely to leave their current employment, perhaps due to family commitments. According to this hypothesis, if employer job search is costly, prospective new employers are less likely to make offers to women than to comparably qualified men. If an offer is made, the current employer - believing that the woman is a loyal servant - is less likely to match the offer.

Section 1 of the paper examines the gender pay gap. Section 2 looks at academic rank, and shows the gender pay gap after allowing for rank. Section 3 considers how the response to outside offers may sustain the gender pay gap. Section 4 examines perceptions of discrimination. Section 5 presents our conclusions.

studies, subject to preserving the anonymity of respondents. 


\section{Pay and Gender}

The Royal Economic Society Working Party on the Representation of Ethnic and Other Minorities in the Economic Profession conducted a survey of academic economists in 1999. We use data from this survey in our analysis. The survey was sent to Heads of Economics Departments in the United Kingdom, who were asked to distribute the forms to full-time academic staff. There was no follow-up to determine whether Heads distributed the forms, and whether or not individuals returned the forms. The survey achieved 516 responses, a response rate of approximately $32 \%$. In a postal survey without follow-up, this is viewed as an acceptable response rate.

Of course given the relatively low response rates typically obtained from postal surveys, it is important to know how representative are the data, in particular with regard to our variables of interest. Compared to Higher Education Statistical Agency data from 1996 reported in Booth and Burton with Mumford (2000), the percentage of women in our sample (16.8\%) is comparable to that in academic economics as a whole $(17.5 \%)$. Moreover, since the cover letter accompanying our survey questionnaire mentioned ethnic minorities but not gender discrimination, there is no reason to expect higher participation by women who might identify with the objectives of the survey. However we do have higher participation by full professors $(25.8 \%$ of our sample compared to $18.8 \%$ in the government data) and from the higher-ranked research departments. This suggests that academics with a greater identification with the national economics profession were more likely to respond, as might be expected.

Blackaby and Frank (2000), who used these data to investigate ethnic differences in pay, provide a more detailed description of the data and the questionnaire. The 
questionnaire contains 44 questions on individual and university characteristics. The data have three characteristics that make them uniquely suitable for the current study. First, there are good productivity measures that can be used to explain earnings. As a result, any measured disparity in earnings across ethnic groups, or across gender, arises after controlling for productivity as well as other individual and workplace characteristics. Second, the survey provides information on labour market experience - such as career breaks, whether or not the individual obtained a promotion internally or from outside, and the extent of outside job offers - that can help explain earnings differentials. Finally, we have data on perceptions of discrimination that can be related to actual labour market experiences. Definitions, means and standard errors of variables are presented in Table 2. In general, we use an estimating sample of the 351 academics who provided complete answers to almost all of the relevant variables. Smaller samples arise when we consider outside offers (341), applications for outside jobs (334), job tenure (348), perceived discrimination (347) and academic rank (349).

The academic labour market in the United Kingdom is a hierarchical one. Individuals are initially employed as lecturers (on either temporary or permanent contracts), and then aim to work their way up the hierarchy to senior lecturer, then reader, and finally to professor. There is not a fixed number of professor positions at the various institutions. There is a salary scale negotiated nationally between the Vice-chancellors and the relevant union for salary ladders within each grade (see also footnote 14, pointing out that there are different scales for the 'new' and 'old' universities). For full professors, there is a nationally negotiated minimum salary, but universities usually negotiate individually with each professor on an annual basis and the top professorial 
salaries can far exceed the top rung of the formal professorial scale. Initial appointees to 'permanent' lectureships are usually not immediately permanent but 'tenure-track', since the incumbent is evaluated for permanency three years after appointment. Tenured lecturers can remain in that rank indefinitely, but can also be promoted at any time in their career. ${ }^{2}$ Senior lectureships are usually rewarded on the basis of three criteria: teaching, research and administration, whereas readerships and professorships are typically rewards for research performance. ${ }^{3}$ Lecturers may be appointed to temporary rather than permanent positions depending on whether the appointment is a replacement for a permanent member of staff on leave, or if the position may be viewed as short-term for funding or other demand-side reasons.

Promotions in UK universities - both internal and external - are subject to welldefined procedures with sizeable appointments or promotions committees. Where in the salary scales for the rank a successful candidate is appointed depends on individual negotiations with the vice-chancellor. Thus, while both promotions and pay are covered by anti-discrimination legislation ${ }^{4}$ and equal opportunities policies, there may be greater procedural safeguards in the case of promotions than pay. In practice, internal promotions are usually appointed at the bottom of the next grade, whereas external promotions are not.

\footnotetext{
${ }^{2}$ Government legislation removed the term 'tenure' for academics with permanency, but in practice an academic who is confirmed in post has job security equivalent to tenure.

${ }^{3}$ Thus UK professorships or 'chairs' are analogous to North American full professors; UK readers/senior lecturers to North American tenured associate professors; and UK lecturers to North American assistant professors. In the UK only the full professor holds the title 'professor' in contrast to North America.

${ }^{4}$ Discrimination is prohibited on grounds of gender, race (including nationality and citizenship) and (in Northern Ireland only) religion. In light of the European Framework Directive, categories covered by antidiscrimination legislation will be extended in 2003 to include religion and sexual orientation, and in 2006 the additional categories of age and disability.
} 
We also have in our data information about research funding obtained by individual academics. Research funding for economics research typically comes from national funding bodies that autonomously allocate funds based on peer review of research applications. Thus although the awards are made on the basis of peer review based on research merit, the awarding decisions are made quite independently of promotion and pay decisions at a particular university. ${ }^{5}$ The means in Table 2 show that women are substantially more likely than men to have had any research funding over the past five years- However, the men who do have external research income are slightly more likely to hold the larger research grants in excess of $£ 100,000$ in the last five years.

We now consider the gender pay gap obtained from a simple earnings equation. Table 1, columns i-iii, presents regression results on the log of earnings that correspond to those in Blackaby and Frank (2000). ${ }^{6}$ This provides a benchmark for our study. All the material after those regressions is new to this paper. The gender gap coefficient in column (i) of Table 1 - controlling only for ethnicity - is approximately $18 \%{ }^{7}$ As seen in Table 2, the average age for women is 41.05 years, and for men, it is 44.78 years.

\footnotetext{
${ }^{5}$ The main funding bodies are the Economic and Social Research Council (ESRC); charitable trusts (such as the Leverhulme Trust and the Nuffield Foundation); the European Commission; and ad hoc projects from government departments.

${ }^{6}$ There are several differences in specification throughout our regressions compared to Blackaby and Frank (2000). We have cleaned the earnings data by removing observations that were not on the nationallynegotiated pay scale for universities. This primarily involved very low reported earnings that were likely to have arisen from part-time staff (although the questionnaire was directed only at full-time staff). This cleaning also removed a small number of staff other than professors who reported large earnings not on the relevant scale for their rank, and may therefore have been including outside (e.g., consultancy) income. There is no maximum pay for full professors, so high professorial earnings were retained. We added an additional explanatory variable, London $5^{*}$, to represent those staff in the two top-rated University of London colleges since it became clear that these departments were paying significantly more than other UK economics departments. This was important in understanding professorial salaries, but had little effect on the gender coefficients. Since we wish to focus upon the overall gender gap, we do not have separate variables for marital status of men and women at this point, although we allow for this in Section 3.

${ }^{7}$ We report the gender gap coefficient in the text here and below to allow for ease of location in the Tables. This is not the percentage difference in earnings between men and women, given that the gender variable is a dummy variable in a semi-logarithmic equation - the actual gender gap percentage is found as [exp(x)-1], with additional adjustments for variance of the samples.
} 
Column (ii) in Table 1 controls for the personal characteristics of age and marital status, and the gender gap coefficient falls to $11 \%$. In column (iii), we add controls for productivity and for workplace characteristics, lowering the gender gap coefficient to $9.8 \%$. Undergraduate degree classification is a measure of ability, and a first class degree has the expected positive coefficient. Holding a $\mathrm{PhD}$ has no significant effect. ${ }^{8}$ High research grant income - in excess of $£ 100,000$ in the last five years - also has a significant positive effect on pay. ${ }^{9}$ Teaching score is a self-reported assessment of teaching performance. Our final productivity measure is the publications score. Following Blackaby and Frank (2000), the score is constructed from the individual's three best (self-selected) lifetime publications, where individuals were asked to choose those that would be most helpful for a Research Assessment Exercise (RAE) submission. ${ }^{10}$ Each publication is given a score using the weightings produced by Laband and Piette (1994). Laband and Piette rank 130 journals based upon citations in 1990 using articles published in 1985-89. ${ }^{11}$ We construct the overall score for an individual as the simple sum of the individual article scores, where the minimum in our

\footnotetext{
${ }^{8}$ Traditionally, a PhD has not been a required entry qualification to university posts in the UK, unlike the US. However, only about $5 \%$ of our sample under the age of 40 fail to have a PhD, compared to $31 \%$ of the sample over 40 .

${ }^{9}$ Research grant income is typically external funding to the individual's employing institution to finance teaching buyouts, research assistance, travel, conference attendance, computers and sometimes a percentage for university overheads. It does not get added to an individual's salary and, in particular, does not provide 'summer salary' for an academic since the UK academic appointment covers the full 12 months of a year.

${ }^{10}$ The RAE has been conducted every four or five years for every department in the UK. For economics, departments list up to four publications for each individual. The Economics panel evaluating these submissions has emphasised traditional international standards, so an individual following the question is likely to list publications in a similar ranking as a US academic. RAE scores go from the highest, $5^{*}$, down to the lowest, 1 , as described in Table 2 .

${ }^{11}$ The reported scores for journals lie between 0 and 100 and 'represent citations per article received by each journal in the reference year as a percentage of the citations per article received by the leading journal'.
} 
sample is 0 and the maximum is $168 .^{12}$ The publications score has a highly significant positive impact on earnings. ${ }^{13}$ Workplace characteristics - other than London location effects - have no significant impact upon earnings. The quality of department (as measured by the 1996 RAE score) has no significant effect. This is not surprising since there are two competing effects - a department seeking to increase its standing will typically pay a wage premium to attract better staff, but - other things being equal - an academic will typically accept a lower wage to be in a higher-ranked department. Given that the national wage scales have an explicit London weighting element, it is not surprising that the London location coefficient is positive. The two top University of London economics departments - the LSE and University College - pay over 20\% more than other universities. Along with Oxford, these are the two departments with the highest score $\left(5^{*}\right)$ in the 1996 RAE. $^{14}$ Oxford, however, as shown by the insignificant coefficient on $5^{*}$ in the estimation, does not pay a wage premium, but arguably provides considerable non-pecuniary benefits.

In examining gender issues, it is important to consider labour market experience variables. Overall experience in the university sector might be associated with higher

\footnotetext{
${ }^{12}$ Since the Laband/Piette weights are from 0 to 100 , the maximum feasible score is 300 . Of the estimating sample, $34 \%$ have 0 publication scores. This may arise either because the individual actually has no countable publications (for example, they may only have published books or articles in books), or because of measurement error. Zero scores do correlate with lower-ranked departments: $53 \%$ of academics in RAE 2 and RAE 1 departments have 0 scores. As a further test that this possible measurement error is not providing our significant gender coefficient, we restrict our sample to those 235 academics in our estimation who have positive publication scores. The gender (male) coefficient in the specification (iii) rises to .104 (t-statistic 2.61).

${ }^{13}$ Blackaby and Frank (2000) experimented with alternative measures of publication productivity, and found little change in the results. Since we only have data on an individual's top three publications, we do not have a quantity measure of output (other than insofar as individuals have fewer than three publications). However, if we only use the individual's top publication rather than top three, there is virtually no change to the results. The preferred publications specification in McDowell et al. (2001) is similar in using articles weighted by journal quality. A potentially better measure of research productivity is to use a citation index for individuals. However, our data set is anonymous, so we have no way of calculating individual citations.
} 
human capital and consequently higher incomes. ${ }^{15}$ Women in our sample spend more years on average on career breaks although they have on average fewer years in nonuniversity employment than men. However, as reported in Table 1(iv), neither experience variable is significant in explaining earnings. The insignificance of career breaks differs from the results for the UK labour market as a whole reported in Swaffield (2000), who finds that 'constraints on labour market activity caused by household or family responsibilities have a negative and significant effect on the wage.' However, the academic labour market is relatively advantageous for individuals taking a career break in that they can continue their research activity while away from a university post. In addition, our results already allow for any fall in measured productivity (such as fewer publications) due to family or other responsibilities.

\footnotetext{
${ }^{14}$ In the most recent RAE, undertaken in 2001, the top-ranking economics departments were the London School of Economics, Essex, Warwick and University College London.

${ }^{15}$ Length of service at a particular university (employer tenure) or in a particular rank (job tenure) is unlikely to be important since there is little reason to expect a high specific human capital component in the academic job market. Indeed, when we introduce variables for length of service into the specification in Table 1(iv) we find insignificant coefficients (t-statistics): employer tenure, -.0019123 (-0.361); employer tenure squared, -.0001253 (-0.848); job tenure, -.007207 (-1.395); and job tenure squared, .0001677 (0.974).
} 


\section{Rank and Gender}

Previous studies across academic disciplines [Ginther and Hayes (2000) for the US and Ward (2000) for Scotland] find that the gender pay gap is explicable on the basis of gender differences in promotions. In this section, we show that there is a significant within-rank gender pay gap, as well as a significant promotions gap. There are a number of reasons why our results may differ from earlier studies. Our sample covers a different country. We consider only one discipline and have quality rather than quantity measures of productivity. These factors may lessen heterogeneity and allow more precise estimates of the gender gaps. Finally, economics is a discipline where there has been a shortage of good applicants, so universities may have engaged in greater salary competition for candidates than in other subjects.

In the UK, there are wage scales for each rank (Lecturer, Senior Lecturer, and Reader) other than Professor (which has a minimum salary level and is then subject to negotiation). ${ }^{16}$ For the non-professorial ranks, individuals will typically move up one increment each year until the top of the scale is reached. However, a female lecturer (for example) could be paid less than a comparable male for three reasons: she might be appointed at a lower point on the scale; she might be less likely to receive accelerated increments awarded at the discretion of the university; or she might be less likely to receive a discretionary merit point when she reaches the top of the scale. There are discretionary merit points at the top of the Lecturer and Senior Lecturer/Reader scales, and our salary data suggests that these are widely used, with approximately $20 \%$ of

\footnotetext{
${ }^{16}$ There are different pay scales for the pre-1992 and post-1992 universities. We ran separate regressions for the two samples, and found no significant differences in the gender coefficient. The relevant 1998/9 pay scales in the traditional (pre-1992) universities run from $£ 16,366$ to $£ 31,894$ for Lecturers, from
} 
Lecturers receiving merit points. Since salaries for Professors are determined by negotiation, there is considerable opportunity for gender differences to arise.

In Table 3(i), we present an ordered probit regression for rank using the same explanatory variables as in our earlier earnings regressions. We find that there is a significant gender effect favouring males. The equation seems well-specified, with ability (as measured by a first class undergraduate degree), publications, and high research income all affecting rank.

We then examine whether - after controlling for rank - there is still a significant gender effect on pay. This regression is shown in Table 3(ii) and shows a large statistically significant within-rank gender gap coefficient of approximately $6 \% .{ }^{17} \mathrm{~A}$ further test is to see if there is a gender effect for specific ranks. We have two ranks (professor and lecturer) with potentially large enough samples to do this examination, and these results are presented in Table $4 .{ }^{18}$ Due to small numbers in the relevant cells, we amalgamate the dummy variables for grant income up to $£ 50,000$ and for grant income from $£ 50,000$ to $£ 100,000$, and also for RAE ranks below 3 . Of the 89 professors in the sample, only 7 are women, and it is perhaps not surprising that the gender gap coefficient is insignificant, although similar in magnitude to the overall within-rank coefficient of

$£ 29,968$ to $£ 33,866$ for Senior Lecturers/Readers, and from $£ 34,560$ upwards for Professors. Senior Lecturers and Readers are on the same salary scale.

${ }^{17}$ Given that there are incremental scales for ranks other than Professor, it might be thought that tenure in rank could explain the within-rank difference since the mean tenure value for men is 7.41 years, while for women it is 6.07 years. When we added job tenure and job tenure-squared, the coefficients for both variables were insignificant at .0032654 (t-statistic 0.888$)$ and $-.0000879(-0.727)$. The inclusion of these variables lowers the male gender coefficient to $5.4 \%$, with a t-statistic of 2.66. Another issue concerns the exogeneity of rank. For example, if women fare poorly in promotions, then a woman holding the rank of lecturer is likely to be more able than the comparable male, and the estimated coefficient on male understates the gender gap. We tried - using the Heckman sample selection technique - to control for this endogeneity, but found that we were unable to identify the sample selection equation since the same variables explain rank and earnings within rank.

${ }^{18}$ An intermediate step is to include terms interacting the male dummy with rank. None of these interactive terms are significant, suggesting that the gender pay gap is not concentrated in specific ranks. 
Table 3(ii). In examining the rank of lecturer, we distinguish between fixed-term lecturers and lecturers holding either permanent or probationary ('tenure-track') contracts. Restricting attention to permanent/probationary lecturers in Table 4(ii), 28 of the 133 academics are female. The gender gap coefficient is $5.1 \%$, and is statistically significant at the $6 \%$ level. ${ }^{19}$ Including fixed-term lecturers in Table 4(iii), the gender gap coefficient rises to $6.3 \%$ (t-statistic 2.63 ).

Outside of the gender gap coefficient, there is not that much to say about the professorial earnings regressions. There is evidence that professorial pay depends upon productivity (grants, publications and teaching). There is also a significantly higher salary paid to appointments from outside over internal promotions. The negative age effect is likely to be due to the changing market for economics professors, with the increased tightness of the market primarily benefiting new (younger) appointments. Not reported in the Table are our experiments in adding administrative responsibilities. Having been Head of Department raised earnings by $7.6 \%$ (t-statistic 1.71 ), while other responsibilities - such as Postgraduate Director - had no effect.

There is no evidence of productivity-related pay for lecturers - all the coefficients on publications, research income and teaching are insignificant [with the exception of high research grant income for the full lecturer sample in 4(iii)]. In contrast, low ability as measured by a lower second or below UK degree - has a clearly negative effect on pay. The larger gender gap coefficient for the sample including temporary lecturers arises since women are more likely to hold temporary contracts [Table 5(i)] and those on temporary contracts are paid less than comparable academics on permanent/probationary

\footnotetext{
${ }^{19}$ The regressions here include job tenure variables. There is no real change to the results if the job tenure and job tenure-squared variables are left out. For example, the gender coefficient in the lecturer equation
} 
contracts [Table 5(ii)]. ${ }^{20}$ Booth and Burton, with Mumford (2000) found - based upon a survey filled out by Heads of Departments rather than individuals - that female economics academics were disproportionately in temporary posts, and that this represented much of the growth in female participation over the period 1996-1998. ${ }^{21}$ Our study confirms the disproportionate number of fixed-term contracts held by females. Out of our estimating sample of 351 academics, $26.67 \%$ of women but only $9.28 \%$ of men hold fixed-term rather than permanent appointments, including junior research posts as well as temporary lectureships. Among younger academics (up to age 40), 44\% of women hold fixed-term appointments compared to $28.17 \%$ of men.

As a further test of our earnings regressions for permanent lecturers, we estimate the pound sterling value of earnings for lecturers in our preferred specification to see if the numerical values are consistent with the nationally negotiated pay scales. The specification of the independent variables in Table 4(iii) differs from that in Table 4(ii) only in the age variables. We take account of our knowledge of the lecturer pay scale which rises on a year-to-year basis for 14 spinal points $^{22}$ - to adopt a spline functional form for the age effect. After experimentation, it became clear that by far the best specification allowed earnings to rise linearly with age to the age of 40 . The equation in (iii) fits well with the actual pay scales in universities. In particular, the actual average annual increment for age is $£ 936$ vs the $£ 688$ shown in the regression. The London

\footnotetext{
goes from .051 to .050 , with the t-statistic changing from 1.88 to 1.86 .

${ }^{20}$ Controlling for rank, the coefficient on temporary contracts is -.157 (t-statistic -5.48 ).

${ }^{21}$ For the UK workforce as a whole, Booth, Francesconi and Frank (2002b) have found evidence that women are more likely than men to be on fixed-term contracts, and that fixed-term contracts have lower salaries than permanent posts.

${ }^{22}$ We use the 1998/99 pay scales to correspond to the sample period. In addition to the 14 standard points, there are three discretionary points to the scale. Spinal point 6 (now the second point on Lecturer scale) is associated in research grades with the appointment of an academic of age 27 . This is consistent with the spline function to age 40 that we adopt.
} 
allowance is $£ 2134$ vs the $£ 2219$ shown in the regression. Women in the regression lose out by about $£ 1554$ relative to men - or about 1.5 increments.

Is there any clear evidence as to whether the gender gap increases or decreases with length of service, or has been increasing or decreasing over time? The research by McDowell, Singell and Ziliak (1999, 2001) suggests that - for US academic economists the promotions gap has been lessening over time. They do not have salary data to examine whether the pay gap has decreased. One way of examining career progression or cohort effects is to introduce an interactive term in gender and age. In the specification of Table 1(iv), this has a coefficient -.0018527 (t-statistic -0.650). Another way is to consider whether the gender gap is increasing or decreasing with income quartiles. Comparing the lowest paid $25 \%$ of men to women, the raw gender gap is $21 \%$; the next quartile, 21\%; the second highest, 17\%; and for the highest paid men and women, $17 \%$. There is thus little evidence that - in the UK - the gender gap is decreasing with new cohorts.

The lack of evidence for a diminishing gender gap in the UK is perhaps not surprising in that the Bett (1999) report has only recently placed gender differentials in academics on the government agenda. There has, for example, been no affirmative action programme comparable to those in the US. The committee chaired by Sir Michael Bett and containing members from university administrations and the trade unions was established in 1998 by the government to examine pay and conditions in higher education. The committee made a large number of recommendations, including the need for a substantial increase in the entry pay for lecturers. It also discovered that there was a significant shortfall in pay for women compared to men, and made recommendations for 
enhanced equal opportunities measures in universities including the possibility of published targets. The bulk of the recommendations of the committee have not yet been enacted. 


\section{Why Are Women Paid Less?}

Why doesn't the market eliminate the earnings differential between men and women? One hypothesis comes from the Report of the Committees on the Status of Women Faculty at MIT (2002). From the Report of the School of Humanities, Arts, and Social Sciences (page 18): "the acquisition of salary increases ... partly depends on obtaining outside offers from other universities, and such outside offers have become increasingly important drivers at MIT over the last decade. To the extent that women are less willing to entertain outside offers, or are less mobile than their male counterparts for personal or family reasons, this trend must inevitably lead to gender discrimination in salaries and working conditions." A 'loyal servants' model of outside offers and gender pay differentials is developed in Booth, Francesconi and Frank (2002a). Although they do not have information on outside offers, they find indirect support in the UK labour market as a whole for the loyal servants hypothesis. In the current data set, we have unique information about outside job offers and we consider whether there is a differential process operating for men and for women.

There is considerable mobility for UK academic economists, so outside offers can play a significant role in determining pay. Overall, $47 \%$ of our sample obtained their current job from outside their university ( $46 \%$ of men and $55 \%$ of women). This differs by rank, with $88 \%$ of temporary lecturers obtaining their post from outside, $53 \%$ of permanent/probationary lecturers, $11 \%$ of senior lecturers/readers, and $39 \%$ of full professors. $^{23}$ In addition to offers from within the UK, academics receive offers from

\footnotetext{
${ }^{23}$ Interestingly, women are more likely than men to obtain the rank of senior lecturer/reader from outside ( $25 \%$ to $12 \%)$ and less likely than men to obtain the rank of professor from outside ( $27 \%$ to $43 \%$ ). However, the size of the sample does not allow further analysis of these differentials. Overall, women are
} 
North America, Europe, Australia, and elsewhere in the world. There has been increased competition for strong researchers due to the institution of the Research Assessment Exercise 20 years ago. This formal national ranking of departments ties government funding to the results, and has provided a strong incentive for universities to recruit the best researchers.

In Table 6(i), we examine whether there is a differential effect for outside offers and other variables - for men and women. ${ }^{24}$ Our sample size (particularly for women) is not large enough to permit the estimation of separate regressions for women and men. We therefore allow (in a single regression) for different male and female coefficients on key variables. In addition to outside offers, we focus upon productivity measures of research grants, publications and teaching ability, as well as marriage. We do not have information on whether the individual has children or child-care responsibilities, and use marriage as a proxy. The column headed F-test compares the male and female coefficients, with the bracketed figure showing the level of significance. In these regressions, we restrict our sample to academics age 35 and older who therefore have a track record in productivity and labour market experiences. ${ }^{25}$ In Table 6.i, the only significant difference between the coefficients for men and women arises with respect to outside offers - men's current salaries are positively correlated with receiving outside

more likely to have obtained their appointment from outside since they are concentrated in posts (temporary and permanent lecturer) where candidates typically are external.

${ }^{24}$ The variables used in the specification are the same as in Table 1(iv) except for the introduction of outside offers. A regression as in Table 1(iv), with the same coefficients for men and women, but introducing outside offers raises the gender coefficient from 9.4 to 9.6, and it remains significant.

${ }^{25}$ The significant variable in our analysis below is outside offers. For younger members of staff, outside offers may arise due to the temporary or probationary nature of their employment, or as they seek to move from an initial post to one that is more consistent with their non-pecuniary preferences - for example, to a different location or to a higher-ranked department. In these cases, outside offers may be less likely to be associated with a higher salary response. In fact, including the full sample of academics, the return to offers to men is .036 (t-statistic 2.77) and to women .004 (0.16). However, the high standard error 
offers over the past five years, whereas women's salaries are negatively correlated. In Table 6(ii) we allow for academic ranks in our earnings estimation. The outside offers effect by gender remains the only significant difference in coefficients. The outside offers variable in Table 6 imposes a structure on the return to multiple offers. An alternative approach is to use a dummy variable for each of the possible values of the outside offer variable - no offers, one offer, 2-5 offers, more than 5 offers. In fact, since only 2 women (and only 1 woman 35 or older) reports more than 5 offers, we constructed dummy variables for one offer and for more than one offer. The coefficients in the earnings regression specification corresponding to Table 6(i) are as follows: men with one offer, .069 (t-statistic 2.18); men with more than one offer, .117 (3.40); women with one offer, -.086 (-1.08); and women with more than one offer, -.182 (-1.61). In the specification corresponding to Table 6(ii), the coefficients are: men with one offer, .008 (0.36); men with more than one offer, .057 (2.37); women with one offer, -.078 (-1.35); and women with more than one offer, $-.220(-2.65)$.

To gain a measure on the magnitude of the outside offers effect, consider a man who receives an outside offer (starting from no offers) in the specification in Table 6(i). He gains $£ 2138$ (based upon the average earnings in the estimation sample), or roughly $6 \%$ of the average male earnings in the sample. This is both a plausible number and one that can lead to substantial gender earnings differentials. It should be noted that the outside offer data refer to offers over the past 5 years while the earnings data are based on current salaries. Despite this time sequence, we are reluctant to push the interpretation of casuality too far since the data were collected as a cross-section survey. Nonetheless, we

associated with the female coefficient means that we cannot reject the hypothesis that the two coefficients are the same (the F-test is significant only at the $15 \%$ level). 
would suggest that the positive correlation between male earnings and outside offers reflects not only the fact that universities are more willing to match men's outside offers but also that men are more likely to accept them. We would suggest that the negative correlation between female earnings and outside offers reflects the fact that some women are dissatisfied with their salary position and therefore seek outside offers - which are not matched or not taken up - as an attempt to rectify the position.

In fact, women in our sample not only get lower returns to outside offers, they are less likely - for given characteristics including productivity - to get outside offers. In the raw data over the entire sample, men have an average value of the outside offer variable of .78 and women .69. Restricting attention to academics age 35 and older, however, the offer disparity is greater; men have an average value of .63 (standard deviation .84) and women .41 (.69). In Table 6(iii), we estimate an ordered probit equation on the determinants of offers for academics 35 and older. In a marginal calculation, men are 18 percentage points more likely to receive any offers than comparable women. Interestingly, career breaks have a negative effect on receiving outside offers and, in this way, can impact negatively on a woman's career and earnings. This effect is in addition to any effect on the individual's career publication record, which is incorporated in our publications measure. The lower numbers of outside offers received by women would also be consistent with the existence of the 'old boys network' and the difficulty that women have experienced gaining access to male networks.

In summary, there is evidence that women receive fewer job offers than men with comparable characteristics (including productivity), that career breaks have an independent negative effect on receiving offers, and that men gain greater earnings 
returns to receiving outside offers. This pattern is consistent with the 'loyal servant' hypothesis that women, perhaps due to family responsibilities, are less mobile than comparable men. If other universities expect that women are less likely to accept offers, and if declined offers are costly to the reputation of the department making the offer or make second choice candidates less likely to accept, then women are less likely to receive offers. When offers are made, the current employer is less likely to match the outside offer because of a belief that the woman is a 'loyal servant' who is unlikely to accept the offer. If women take career breaks, both prospective and current employers can take this as a signal that the woman is less mobile.

Of course, women could gain a lower earnings response to outside offers due to the heterogeneity of outside offers. Women who receive offers may be obtaining them from lower-ranked departments, or from non-academic employers, compared to men with equivalent observable characteristics. The current employer would fail to match the outside offer not because the woman is less mobile in principle, but because the outside offer is unattractive. However, this does not contradict the loyal servant hypothesis. Just as women may receive fewer offers than comparable men because they are perceived to be less mobile, they may also receive less desirable offers. A lower ranked department may make an offer, even though it expects the woman to decline it, if she is sufficiently more qualified than male candidates.

Since outside offers are the only characteristic with a different return to men and women, and given the size of the sample, it is not meaningful to try and decompose the overall gender pay gap into components representing different characteristics and different returns to characteristics. However, it is interesting to examine whether women 
in the sample do have significantly different average characteristics other than age. In fact, the difference in age explains many of the observed differences in variable means between men and women. For example, the difference in marriage rates between men and women is insignificant once we control for age. There is, however, an important variable where there is a gender difference, and that is in publication scores as shown in the tobit estimation in Table 7(i). Other things being equal, a male academic economist will have a higher publication score by 8.639 . This translates into a gap of $£ 555$ on top of the $£ 3144$ gender gap based upon the gender regression coefficient in Table 1(iv). One hypothesis is that the lower measured publications productivity for women might arise if women are disproportionately located in fields of research that have lower publication rankings. In our data, economists specialising in econometrics, microeconomics and labour economics have the highest average publications score. ${ }^{26}$ Women are in fact more highly represented in these three fields ( $53 \%$ vs $48 \%$ for men), so field of research is unable to explain the publications gap. The 'loyal servant' hypothesis provides a possible explanation in that women - who are less likely to leave their current employer - may devote more effort than men to other components of their job such as teaching and administration. Another possibility is that the effect reflects child-rearing responsibilities by women that affect their research productivity. Interestingly, though, there is no significant negative effect on obtaining research grants. It should be noted that research grants are typically awarded either by the Economic and Social Research Council, a government-funded agency, or by national private foundations. These institutions may well have adopted equal opportunities policies more effectively than universities.

\footnotetext{
${ }^{26}$ Interestingly to the authors, labour economists have the highest average publications score by field in the UK.
} 


\section{Perceptions of Discrimination}

The data also include interesting information about perceptions of discrimination. The survey asked: "Do you feel that you have suffered unfair discrimination in employment?" While $19.71 \%$ of men answered yes, $42.35 \%$ of women felt that they had suffered discrimination. For the women reporting discrimination, $72.73 \%$ felt that it was based upon gender. The survey also asked when the perceived discrimination occurred, and $25.88 \%$ of women felt that they had suffered discrimination within the last 5 years. In this section, we ask whether there is evidence that these perceptions are based upon reality, and whether they affect behaviour in a consistent manner.

There is evidence from our data that individuals with earnings below that predicted on the basis of their characteristics believe that the difference is in fact associated with discrimination. We estimated a probit equation on recent (within the last 5 years) perceived discrimination, reported in Table 7(ii). The estimation is over the full sample, including both men and women, since men also reported discrimination on the basis of, for example, age. We introduce into the analysis the 'unexplained earnings' of an individual, and allow for separate variables for men and women. These values are derived by taking the residuals of the regression specification in Table 1(iv). The regression shows that women are more likely to have perceived recent discrimination, as are those individuals with a degree from overseas (representing possible nationality and ethnicity discrimination), along with those in new (typically less prestigious) universities. Having received positive but modest grant income (up to $£ 50,000$ ) also enters positively in perceived discrimination, possibly because individuals overweight small grant income above universities' actual preferences. Importantly, there is a negative and significant 
coefficient on the unexplained part of the individual's earnings for women (significant at the 5.6\% level). That is, a woman whose earnings are less than predicted by the observable characteristics is more likely to have perceived discrimination within the last five years. ${ }^{27}$ This result suggests that women - rightly or wrongly - ascribe unexplained earnings differentials to discrimination.

Do individuals behave in a manner reflecting their belief that they are suffering from discrimination? In the UK, there is a formal system of applications for jobs, and even at the full professor level - individuals typically submit a formal application for the post. Individuals who believe they are suffering low incomes at their current institution due to discrimination might be expected to submit more applications for new jobs. We estimate the determinants of applications in Table 7(iii), restricting our attention to the sample of individuals aged 35 and over for the same reasons as in the previous section. The 'unexplained earnings' values are derived by taking the residual of the regression specification in Table 1(iv), re-estimated for the sample of individuals over the age of 34 . In 7(iii), the gender coefficient is insignificant, but the unpredicted earnings coefficient for women is significantly negative and different from the (positive but insignificant) coefficient for men. The negative coefficient supports the hypothesis that women with low earnings (relative to the expected level for their characteristics, including gender) submit more job applications than other individuals. However, the analysis in Section 3 suggests that these women are unlikely to bridge the earnings gap since our results show that women are less likely to receive outside offers and gain lower earnings returns to

\footnotetext{
${ }^{27}$ As noted in the text, this experiment is conducted over all individuals, and therefore includes all forms of perceived discrimination. If we restrict attention to gender discrimination, and use as predicted earnings for women a figure not allowing for the average gender gap coefficient in Table 1(iv) - that is, we add .094 to
} 
outside offers. An additional effect arises when there is perceived recent discrimination. Individuals perceiving discrimination apply for new jobs, even if their pay is at the appropriate level predicted by the earnings regression for an individual of their characteristics.

the predicted log earnings for women - the coefficient on the unexplained component of an individual's earnings is larger and more significant. 


\section{Conclusions}

In our sample of academic economists in the UK, we find that there is a significant gender gap in pay after adjusting for productivity. Although there is evidence that women are disadvantaged in promotions, there is also a within-rank pay gap. Effective policies to remedy the pay gap must therefore look not only at promotions, but also at entry wages, accelerated increments and discretionary points at the top of Lecturer and Senior Lecturer scales. We confirm the findings in Booth et al. (2000) that females are disproportionately represented in temporary appointments, and that these posts are poorly remunerated compared to permanent appointments.

We find no evidence from the earnings regressions that the pay gap is directly due to career breaks or experience in the labour market outside the university sector. There is a possible indirect route since career breaks have a negative effect on outside offers, which in turn have a positive effect on earnings. More generally, the only variable that has a significantly different impact for men and women is outside offers. For men, but

not for women, these have the expected positive impact on earnings. Further, men are more likely than comparable women to receive outside offers.

There is evidence that women have lower publications productivity than men with comparable characteristics. It is possible that this is an indirect effect of women devoting effort to child-raising. Alternatively, since there is no evidence that women are less productive in teaching and obtaining research grants, women may not be receiving the same advice on publications as new male entrants to the profession. This suggests an important role for mentoring for new female entrants to the profession. However, the lower publications score - given the high weightings on journal quality in our measure - 
may also reflect the disproportionate representation of women in temporary posts. Many economists get their best publications (as measured by journal quality) in the first years of their career. New entrants in temporary posts may not have the luxury to send their first articles to the very top journals, with high rejection rates, since they may need quick publications to gain a permanent post.

There is evidence in our data that individuals suffering from a pay gap - relative to their observable characteristics - attribute this to discrimination. We find that perceived discrimination is highly correlated with the unexplained component of earnings. It is not correlated with predicted earnings. Further, women (but not men) with earnings below the predicted level make a greater number of job applications. However, given the differential response to outside offers for men and women, women in this situation are unlikely to bridge the earnings gap.

Unlike previous studies (which show only a promotions gap), our analysis shows a consistent pattern of less favourable labour market experiences for women in academic economics. As argued by Lazear and Rosen (1990), it is hard to understand why women should be disadvantaged in promotions and not in other labour market experiences. In this sense, our results present a plausible combination of results. Women are less likely (for given observable characteristics) to be promoted, they receive lower wages in a given rank, they receive fewer job offers, gain lower financial rewards to outside offers, and they perceive gender discrimination.

To what extent are these results from the academic labour market applicable more generally in the economy? Non-profit institutions are isolated from the rigours of the market economy, and in that sense could more easily follow tastes for discrimination. 
However, they are subject to government objectives and policies, and the UK government and the European Union have adopted strong positions in favour of equal opportunities. Overall, though, our conclusion is that the data support the loyal servant hypothesis. The results are consistent with a model where universities are paying women less as an optimal cost-minimising strategy, rather than as a taste for discrimination. If that is the case, and if the results apply as well to the private sector, then the market economy will not eliminate these differentials without government intervention. 


\section{References}

Baker, G, M Gibbs and B Holmstrom, 1994, 'The internal economics of the firm: evidence from personnel data', Quarterly Journal of Economics, 109, 881919.

Bett, M., 1999, 'Independent review of higher education pay and conditions', HMSO London

Blackaby, D and J Frank, 2000, 'Ethnic and other minority representation in UK academic economics', The Economic Journal, (110:June), F293-F311.

Booth, A L and J Burton, with K Mumford, 2000, 'The Position of women in UK academic economics', The Economic Journal, (110:June), F312-F333.

Booth, A L, M Francesconi and J Frank, 2002a, 'A sticky floors model of promotion, pay, and gender', European Economics Review, in press.

Booth, A L, M Francesconi and J Frank, 2002b, 'Temporary jobs: stepping stones or dead ends?', Economic Journal, in press.

Ginther, D and K J Hayes, 1999, 'Salary and promotion differentials by gender for faculty in the humanities', American Economic Review Papers and Proceedings, (89:2), 52-6.

Ginther, D and $\mathrm{K} \mathrm{J}$ Hayes, 2000, 'Changes in gender salary and promotion differentials 1977-1995 for faculty in the humanities', mimeo.

Laband, D N and M J Piette, 1994, 'The relative impacts of economics journals: 1970 - 1990', Journal of Economic Literature, (32), 640-66.

Lazear, E, 2000, 'Performance pay and productivity', American Economic Review, 90(5), 1346-1361.

Lazear, E and S Rosen, 1990, 'Male-female wage differentials in job ladders', Journal of Labor Economics, (8:1, part 2), S106-23.

MIT, 1999, 'A study on the status of women faculty in science at MIT', MIT Faculty Newsletter, 11(4), Special edition, March.

MIT, 2002, 'Report of the committees on the status of women faculty at MIT', Office of the Provost.

McDowell, J, L Singell and J Ziliak, 1999, 'Cracks in the glass ceiling: gender and promotion in the economics profession', American Economic Review Papers and Proceedings, (89:2), 397-402. 
McDowell, J, L Singell and J Ziliak, 2001, 'Gender and promotion in the Economics profession', Industrial and Labor Relations Review, (54:2), 224-44.

Swaffield, J, 2000, 'Gender, motivation, experience and wages', Centre for Economic Performance Discussion Paper \#457, May.

Ward, M., 2000, 'Salary determination and the gender salary gap in British academia', mimeo. 
TABLE 1: The Determinants of Log Earnings (OLS Estimates)

\begin{tabular}{|c|c|c|c|c|c|c|c|c|}
\hline \multirow[b]{2}{*}{ Variables } & \multicolumn{2}{|c|}{$\mathbf{i}$} & \multicolumn{2}{|c|}{$\mathbf{I i}$} & \multicolumn{2}{|c|}{ Iii } & \multicolumn{2}{|c|}{ iv } \\
\hline & Coeff & t-stat & Coeff & t-stat & Coeff & t-stat & Coeff & t-stat \\
\hline Constant & 10.232 & 273.284 & 8.614 & 37.93 & 8.43 & 41.31 & 8.483 & 40.38 \\
\hline \multicolumn{9}{|l|}{ Individual characteristics } \\
\hline \multicolumn{9}{|l|}{ White } \\
\hline Black/Asian & -.111 & -1.82 & -.065 & -1.40 & -.072 & -1.82 & -.066 & -1.65 \\
\hline Other ethnic & -.044 & -0.57 & -.016 & -0.27 & -.041 & -0.79 & -.041 & -0.80 \\
\hline Male & .177 & 4.41 & .110 & 3.54 & .098 & 3.75 & .094 & 3.58 \\
\hline Married & & & .033 & 1.19 & .040 & 1.69 & .040 & 1.68 \\
\hline Age & & & .058 & 5.49 & .058 & 6.16 & .057 & 5.88 \\
\hline Age squared x 10 & & & -.004 & -3.88 & -.004 & -4.44 & -.004 & -4.23 \\
\hline \multicolumn{9}{|l|}{ Productivity } \\
\hline Degree: UK first class & & & & & .044 & 1.83 & .046 & 1.90 \\
\hline \multicolumn{9}{|l|}{ Degree: UK upper second } \\
\hline Degree: other UK & & & & & -.059 & -1.62 & -.061 & -1.67 \\
\hline Degree: overseas & & & & & .015 & 0.53 & .016 & 0.57 \\
\hline $\mathrm{PhD}$ & & & & & .011 & 0.44 & .015 & 0.59 \\
\hline Publications score x 10 & & & & & .021 & 6.20 & .020 & 6.17 \\
\hline \multicolumn{9}{|l|}{ Research income: none } \\
\hline Research income: up to $50 \mathrm{k}$ & & & & & -.009 & -0.41 & -.007 & -0.32 \\
\hline Research income: $50-100 \mathrm{k}$ & & & & & .100 & 0.44 & .106 & 2.48 \\
\hline Research income: over $100 \mathrm{k}$ & & & & & .130 & 4.26 & .129 & 4.21 \\
\hline Teaching score & & & & & .039 & 3.11 & .039 & 3.04 \\
\hline \multicolumn{9}{|l|}{ Workplace characteristics } \\
\hline RAE 5* & & & & & .014 & 0.29 & .007 & 0.14 \\
\hline RAE 5 & & & & & .003 & 0.12 & .003 & 0.12 \\
\hline \multicolumn{9}{|l|}{ RAE 4} \\
\hline RAE 3 & & & & & -.002 & -0.09 & -.000 & -0.02 \\
\hline RAE 2 & & & & & -.002 & -0.04 & .002 & 0.04 \\
\hline RAE 1 & & & & & -.058 & -1.24 & -.056 & -1.20 \\
\hline RAE N/A & & & & & .010 & 0.11 & .008 & 0.09 \\
\hline Old university & & & & & -.031 & -0.89 & -.028 & -0.80 \\
\hline London & & & & & .052 & 1.73 & .048 & 1.60 \\
\hline London $5^{*}$ & & & & & .208 & 3.36 & .215 & 3.44 \\
\hline \multicolumn{9}{|l|}{ Other England } \\
\hline Wales/N. Ireland & & & & & -.019 & -0.40 & -.024 & -0.48 \\
\hline Scotland & & & & & .025 & 0.74 & .021 & 0.63 \\
\hline \multicolumn{9}{|l|}{ Labour Market Experience } \\
\hline External & & & & & & & -.013 & -0.63 \\
\hline Career break & & & & & & & -.005 & -1.03 \\
\hline Non-academic experience & & & & & & & .001 & 0.75 \\
\hline Sample size & 351 & & 351 & & 351 & & 351 & \\
\hline Adjusted R-squared & .058 & & .45 & & .64 & & .64 & \\
\hline
\end{tabular}


TABLE 2: Definitions and Means (Standard Deviations) of Variables

\begin{tabular}{|c|c|c|c|c|}
\hline Variable Means & Overall & Men & Women & Notes and Definitions \\
\hline Earnings & $\begin{array}{c}33,324 \\
(10,415)\end{array}$ & $\begin{array}{c}34,312 \\
(10,534)\end{array}$ & $\begin{array}{l}28,531 \\
(8,364)\end{array}$ & $\begin{array}{l}\text { Self-reported annual gross university } \\
\text { salary in pounds sterling }\end{array}$ \\
\hline \multicolumn{5}{|l|}{ Individual characteristics } \\
\hline White & .89 & .91 & .83 & \\
\hline Black/Asian & .07 & .06 & .10 & \\
\hline Other ethnic & .04 & .03 & .07 & \\
\hline Male & .83 & & & \\
\hline Married & .74 & .77 & .62 & 'Married' is married and living together \\
\hline Age & $\begin{array}{l}44.14 \\
(9.77)\end{array}$ & $\begin{array}{l}44.78 \\
(9.76)\end{array}$ & $\begin{array}{l}41.05 \\
(9.32)\end{array}$ & \\
\hline \multicolumn{5}{|l|}{ Productivity } \\
\hline Degree: UK first class & .28 & .30 & .22 & \\
\hline Degree: UK upper second & .40 & .40 & .37 & Rank-ordering of UK undergraduate \\
\hline Degree: other UK & .09 & .09 & .08 & degree results \\
\hline Degree: overseas & .23 & .21 & .33 & Overseas undergraduate degree \\
\hline $\mathrm{PhD}$ & .78 & .77 & .80 & Has a PhD \\
\hline Publications score & $\begin{array}{c}27.33 \\
(31.94)\end{array}$ & $\begin{array}{c}29.10 \\
(32.40)\end{array}$ & $\begin{array}{c}18.73 \\
(28.33)\end{array}$ & $\begin{array}{l}\text { Citation-weighted (by journal) index of } \\
\text { top } 3 \text { career articles }\end{array}$ \\
\hline Research income: none & .55 & .56 & .48 & External research grant funding in last \\
\hline Research income: up to $50 \mathrm{k}$ & .26 & .25 & .30 & five years. In the UK, external funding \\
\hline Research income: $50-100 \mathrm{k}$ & .06 & .04 & .10 & rarely provides additional income to the \\
\hline Research income: over $100 \mathrm{k}$ & .13 & .14 & .12 & $\begin{array}{l}\text { academic, but covers research expenses, } \\
\text { research assistance and occasionally } \\
\text { teaching 'buy outs'. }\end{array}$ \\
\hline Teaching score & $\begin{array}{l}2.58 \\
(.78)\end{array}$ & $\begin{array}{l}2.59 \\
(.78)\end{array}$ & $\begin{array}{l}2.57 \\
(.79)\end{array}$ & $\begin{array}{l}\text { Self-assessed rating as a teacher from } 0 \\
\text { (weak) to } 4 \text { (outstanding) }\end{array}$ \\
\hline \multicolumn{5}{|l|}{ Workplace characteristics } \\
\hline RAE 5* & .13 & .12 & .18 & UK government agency ranking \\
\hline RAE 5 & .23 & .24 & .15 & (Research Assessment Exercise) of all \\
\hline RAE 4 & .31 & .31 & .29 & economics subject groups (departments \\
\hline RAE 3 & .16 & .15 & .17 & or groups within other departments - \\
\hline RAE 2 & .09 & .08 & .10 & such as economists in a management \\
\hline RAE 1 & .09 & .09 & .08 & school), going from $5^{*}$ (best) down to 1 \\
\hline RAE N/A & .01 & .01 & .03 & (lowest). Based on 1996 results. \\
\hline Old university & .71 & .72 & .67 & $\begin{array}{l}\text { Pre-1994 university (university status } \\
\text { was granted to polytechnics in 1994) }\end{array}$ \\
\hline London & .23 & .22 & .27 & Including the category London $5 *$ \\
\hline London $5^{*}$ & .08 & .08 & .10 & $\begin{array}{l}\text { London departments obtaining the top } \\
\left(5^{*}\right) \text { ranking in the } 1996 \mathrm{RAE}\end{array}$ \\
\hline Other England & .61 & .63 & .60 & \\
\hline Wales/N. Ireland & .05 & .04 & .05 & \\
\hline Scotland & .11 & .11 & .08 & \\
\hline \multicolumn{5}{|l|}{ Labour Market Experience } \\
\hline External & .44 & .43 & .48 & $\begin{array}{l}\text { Whether current rank was obtained as an } \\
\text { appointment from outside }\end{array}$ \\
\hline Career break & $\begin{array}{r}1.96 \\
(2.39)\end{array}$ & $\begin{array}{c}1.91 \\
(2.33)\end{array}$ & $\begin{array}{l}2.18 \\
(2.65)\end{array}$ & $\begin{array}{l}\text { Potential years in labour market } \\
\text { (calculated from entry date) less years } \\
\text { reported as being in the labour market }\end{array}$ \\
\hline Non-academic experience & $\begin{array}{r}4.05 \\
(6.55)\end{array}$ & $\begin{array}{c}4.32 \\
(5.70)\end{array}$ & $\begin{array}{l}2.77 \\
(9.63)\end{array}$ & $\begin{array}{l}\text { Reported years in labour market less } \\
\text { reported years in the university sector }\end{array}$ \\
\hline
\end{tabular}




\begin{tabular}{|c|c|c|c|c|}
\hline Outside offers & $\begin{array}{c}.76 \\
(.89)\end{array}$ & $\begin{array}{l}.78 \\
(.90)\end{array}$ & $\begin{array}{l}.69 \\
(.89)\end{array}$ & $\begin{array}{l}\text { Reported outside offers (other than } \\
\text { current post) in last five years with } \\
\text { values } 0 \text { (no offers), } 1 \text { ( } 1 \text { offer), } 2 \text { ( } 2-5 \\
\text { offers), } 3 \text { (more than } 5 \text { offers) }\end{array}$ \\
\hline Applications & $\begin{array}{l}1.72 \\
(.85)\end{array}$ & $\begin{array}{l}1.73 \\
(.85)\end{array}$ & $\begin{array}{l}1.65 \\
(.84)\end{array}$ & $\begin{array}{l}\text { Reported applications submitted in last } \\
\text { five years with values } 1 \text { (no } \\
\text { applications), } 2 \text { ( } 1-5 \text { applications), } 3 \\
\text { (more than } 5 \text { applications) }\end{array}$ \\
\hline Job Tenure & $\begin{array}{c}7.41 \\
(7.35)\end{array}$ & $\begin{array}{c}7.76 \\
(7.58)\end{array}$ & $\begin{array}{c}5.63 \\
(5.86)\end{array}$ & Years in current post \\
\hline Employer Tenure & $\begin{array}{l}11.52 \\
(9.83)\end{array}$ & $\begin{array}{c}12.12 \\
(10.08)\end{array}$ & $\begin{array}{c}8.67 \\
(7.98)\end{array}$ & Years with current employer \\
\hline \multicolumn{5}{|l|}{ Academic Rank } \\
\hline Professor & .25 & .28 & .12 & US Full professor \\
\hline Reader/Senior Lecturer & .23 & .24 & .13 & US Associate professor \\
\hline Lecturer & .38 & .36 & .47 & US tenure-track Assistant professor \\
\hline Temporary Lecturer & .09 & .07 & .20 & Fixed-term contract lecturer \\
\hline Research Officer & .05 & .05 & .08 & Senior or junior researcher \\
\hline Sample size & 351 & 291 & 60 & $\begin{array}{l}\text { sample size is } 341 \text { for outside offers, } 334 \\
\text { for job applications, } 348 \text { for job tenure } \\
\text { and employer tenure, } 347 \text { for perceived } \\
\text { discrimination and } 349 \text { for rank }\end{array}$ \\
\hline
\end{tabular}


TABLE 3: The Determinants of Rank and In-rank Earnings

\begin{tabular}{|c|c|c|c|c|}
\hline \multirow{5}{*}{$\begin{array}{l}\text { Variables } \\
\text { Estimation Method and } \\
\text { Dependent variable } \\
\text { Constant } \\
\text { Individual characteristics } \\
\end{array}$} & \multicolumn{2}{|c|}{$\mathbf{i}$} & \multicolumn{2}{|c|}{ ii } \\
\hline & Coeff & z-stat & Coeff & t-stat \\
\hline & \multirow{3}{*}{\multicolumn{2}{|c|}{$\begin{array}{l}\text { Ordered Probit on } \\
\text { Rank }\end{array}$}} & \multicolumn{2}{|c|}{ OLS Log Earnings } \\
\hline & & & 9.028 & 55.56 \\
\hline & & & & \\
\hline \multicolumn{5}{|l|}{ White } \\
\hline Black/Asian & -.147 & -0.58 & -.053 & -1.77 \\
\hline Other ethnic & -.297 & -0.85 & -.007 & -0.18 \\
\hline Male & .464 & 2.66 & .055 & 2.76 \\
\hline Married & .361 & 2.26 & .022 & 1.20 \\
\hline Age & .298 & 4.19 & .035 & 4.73 \\
\hline Age squared x 10 & -.023 & -2.98 & -.003 & -3.71 \\
\hline \multicolumn{5}{|l|}{ Productivity } \\
\hline Degree: UK first class & .489 & 3.00 & -.008 & -0.45 \\
\hline \multicolumn{5}{|l|}{ Degree: UK upper second } \\
\hline Degree: other UK & -.278 & -1.16 & -.037 & -1.35 \\
\hline Degree: overseas & .354 & 1.86 & -.011 & -0.54 \\
\hline $\mathrm{PhD}$ & .409 & 2.37 & -.020 & -1.03 \\
\hline Publications score $\mathrm{x} 10$ & .165 & 6.48 & .005 & 1.85 \\
\hline \multicolumn{5}{|l|}{ Research income: none } \\
\hline Research income: up to $50 \mathrm{k}$ & .022 & 0.14 & -.004 & -0.27 \\
\hline Research income: $50-100 \mathrm{k}$ & .584 & 1.93 & .039 & 1.21 \\
\hline Research income: over $100 \mathrm{k}$ & .790 & 3.70 & .055 & 2.36 \\
\hline Teaching score & .106 & 1.25 & .033 & 3.48 \\
\hline \multicolumn{5}{|l|}{ Workplace characteristics } \\
\hline RAE 5* & -.304 & -0.93 & .029 & 0.79 \\
\hline RAE 5 & -.104 & -0.54 & .000 & 0.02 \\
\hline \multicolumn{5}{|l|}{ RAE 4} \\
\hline RAE 3 & -.018 & -0.08 & -.011 & -0.45 \\
\hline RAE 2 & -.085 & -0.27 & .014 & 0.41 \\
\hline RAE 1 & -.285 & -0.91 & -.018 & -0.52 \\
\hline RAE N/A & -.642 & -0.97 & .078 & 1.07 \\
\hline Old university & -.105 & -0.45 & -.009 & -0.36 \\
\hline London & .005 & 0.03 & .058 & 2.56 \\
\hline London 5* & .419 & 1.02 & .174 & 3.69 \\
\hline \multicolumn{5}{|l|}{ Other England } \\
\hline Wales/N. Ireland & -.282 & -0.88 & .003 & 0.08 \\
\hline Scotland & .225 & 0.99 & .001 & 0.06 \\
\hline \multicolumn{5}{|l|}{ Labour Market Experience } \\
\hline External & -.479 & -3.29 & .020 & 1.22 \\
\hline Career break & -.040 & -1.26 & .000 & 0.21 \\
\hline Non-academic experience & .004 & 0.39 & .000 & 0.00 \\
\hline \multicolumn{5}{|l|}{ Rank } \\
\hline Professor & & & .447 & 9.72 \\
\hline Reader/Senior Lecturer & & & .215 & 4.76 \\
\hline Lecturer & & & .095 & 2.43 \\
\hline Temporary Lecturer & & & -.055 & -1.59 \\
\hline \multicolumn{5}{|l|}{ Research Officer } \\
\hline Sample size & 349 & & 349 & \\
\hline Log likelihood & -341.125 & & & \\
\hline Adjusted R-squared & $0.30(\mathrm{ps}$ & do R-sq) & 0.79 & \\
\hline
\end{tabular}


TABLE 4: The Determinants of Earnings by Rank

\begin{tabular}{|c|c|c|c|c|c|c|c|c|}
\hline \multirow{3}{*}{$\begin{array}{l}\text { Variables } \\
\text { Estimation Method and } \\
\text { Dependent Variable }\end{array}$} & \multicolumn{2}{|c|}{$\mathbf{i}$} & \multicolumn{2}{|c|}{ ii } & \multicolumn{2}{|c|}{ iii } & \multicolumn{2}{|c|}{ iv } \\
\hline & Coeff & t-stat & Coeff & t-stat & Coeff & t-stat & Coeff & t-stat \\
\hline & \multicolumn{2}{|c|}{$\begin{array}{c}\text { OLS Professor Log } \\
\text { Earnings }\end{array}$} & \multicolumn{2}{|c|}{$\begin{array}{l}\text { OLS Permanent } \\
\text { Lecturer Log } \\
\text { Earnings }\end{array}$} & \multicolumn{2}{|c|}{$\begin{array}{l}\text { OLS All Lecturer } \\
\text { Log Earnings }\end{array}$} & \multicolumn{2}{|c|}{$\begin{array}{l}\text { OLS Lecturer } \\
\text { Earnings }\end{array}$} \\
\hline \multicolumn{8}{|l|}{ Individual characteristics } & 0.82 \\
\hline White & & & & & & & & \\
\hline Black/Asian & -.094 & -1.00 & -.006 & -0.15 & -.010 & -0.14 & -434.31 & -0.39 \\
\hline Other ethnic & .328 & 1.80 & -.025 & -0.55 & -.016 & -0.34 & -1313.17 & -1.03 \\
\hline Male & .034 & 0.44 & .051 & 1.88 & .063 & 2.63 & 1554.50 & 2.06 \\
\hline Married & .030 & 0.62 & -.000 & -0.01 & .006 & 0.26 & -205.00 & -0.28 \\
\hline Age & -.049 & -1.66 & .058 & 3.81 & .061 & 4.29 & & \\
\hline Age squared x 10 & .005 & 1.91 & -.005 & -3.00 & -.005 & -3.45 & & \\
\hline Age up to 40 & & & & & & & 688.80 & 6.16 \\
\hline \multicolumn{9}{|l|}{ Productivity } \\
\hline $\begin{array}{l}\text { Degree: UK first class } \\
\text { Degree: UK upper second }\end{array}$ & -.026 & -0.61 & -.022 & -0.74 & -.026 & -0.93 & -894.52 & -1.10 \\
\hline Degree: other UK & -.019 & -0.24 & -.093 & -2.46 & -.096 & -2.54 & -2526.38 & -2.46 \\
\hline Degree: overseas & .002 & 0.04 & -.025 & -0.70 & -.007 & -0.23 & -489.15 & -0.50 \\
\hline $\mathrm{PhD}$ & -.028 & -0.56 & -.004 & -0.16 & -.009 & -0.30 & 101.80 & 0.12 \\
\hline Publications score x 10 & .007 & 1.41 & .005 & 0.67 & .004 & 0.80 & 175.22 & 1.06 \\
\hline \multicolumn{9}{|l|}{ Research income: none } \\
\hline Research income: up to $100 \mathrm{k}$ & .038 & 0.89 & -.038 & -1.48 & .001 & 0.07 & -1245.34 & -1.75 \\
\hline Research income: over $100 \mathrm{k}$ & .075 & 1.58 & .062 & 1.47 & .095 & 2.30 & 1620.47 & 1.38 \\
\hline Teaching score & .059 & 2.59 & -.004 & -0.30 & -.006 & -0.47 & -121.85 & -0.29 \\
\hline \multicolumn{9}{|l|}{ Workplace characteristics } \\
\hline RAE 5* & -.226 & -1.91 & .037 & 0.67 & .028 & 0.52 & 1371.74 & 0.90 \\
\hline RAE 5 & -.031 & -0.62 & -.036 & -0.88 & -.063 & -1.88 & -1421.33 & -1.28 \\
\hline \multicolumn{9}{|l|}{ RAE 4} \\
\hline RAE 3 & .064 & 0.63 & .028 & 0.82 & -.005 & -0.16 & 529.50 & 0.5 \\
\hline RAE 2 or below & -.185 & -1.51 & -.033 & -0.82 & -.044 & -1.08 & -758.87 & -0.69 \\
\hline Old university & -.010 & -0.13 & -.035 & -1.05 & -.049 & -1.49 & -1522.21 & -1.68 \\
\hline London & .045 & 0.54 & .088 & 2.91 & .090 & 3.12 & 2219.84 & 2.68 \\
\hline London 5* & .409 & 2.67 & .266 & 2.90 & .130 & 1.89 & 7163.32 & 2.87 \\
\hline \multicolumn{9}{|l|}{ Other England } \\
\hline Wales/N. Ireland & .045 & 0.54 & .031 & -0.55 & -.011 & -0.19 & -1000.29 & -0.65 \\
\hline Scotland & -.026 & -0.36 & -.033 & -0.87 & -.030 & -0.83 & -1191.74 & -1.13 \\
\hline \multicolumn{9}{|l|}{ Labour Market Experience } \\
\hline External & .121 & 3.17 & -.003 & -0.14 & -.015 & -0.58 & -341.85 & -0.45 \\
\hline Career break & -.002 & -0.20 & -.006 & -1.27 & -.005 & -0.97 & -139.42 & -0.97 \\
\hline Non-academic experience & .002 & 0.56 & .001 & 0.52 & .001 & 0.79 & 26.95 & 0.41 \\
\hline Job tenure & -.004 & -0.50 & .002 & 0.42 & .010 & 1.56 & 78.84 & 0.44 \\
\hline Job tenure squared x 10 & .000 & 0.38 & -.001 & -0.55 & -.003 & -1.37 & -17.65 & -0.30 \\
\hline Sample size & 88 & & 133 & & 166 & & 133 & \\
\hline Adjusted R-squared & 0.41 & & 0.46 & & 0.56 & & 0.44 & \\
\hline
\end{tabular}


TABLE 5: Fixed-term Contracts

\begin{tabular}{|c|c|c|c|c|}
\hline & $\mathbf{i}$ & & & \\
\hline Variables & Coeff & t-stat & Coeff & z-stat \\
\hline Estimation Method and & OLS Log $\mathrm{E}$ & Earnings & Probit 1 & ed-term \\
\hline Constant & 8820 & 4084 & $\begin{array}{cc}c 0 \\
6458\end{array}$ & 170 \\
\hline Individual characteristics & & & & \\
\hline White & & & & \\
\hline Black/Asian & -.067 & -1.73 & -.266 & -0.55 \\
\hline Other ethnic & -.049 & -.996 & -.388 & -0.51 \\
\hline Male & .074 & 2.85 & -.911 & -2.80 \\
\hline Married & .031 & 1.33 & -.538 & -1.74 \\
\hline Age & .045 & 4.65 & -.230 & -1.14 \\
\hline Age squared x 10 & -.000 & -3.21 & .001 & 0.56 \\
\hline Productivity & & & & \\
\hline Degree: UK first class & .042 & 1.82 & .208 & 0.55 \\
\hline Degree: UK upper second & & & & \\
\hline Degree: other UK & -.059 & -1.66 & -.144 & -0.17 \\
\hline Degree: overseas & .012 & 0.44 & -.218 & -0.51 \\
\hline $\mathrm{PhD}$ & .008 & 0.34 & -.598 & -1.15 \\
\hline Publications score x 10 & .018 & 5.69 & -.231 & -2.80 \\
\hline Research income: none & & & & \\
\hline Research income: up to $50 \mathrm{k}$ & -.017 & -0.75 & -.369 & -0.96 \\
\hline Research income: $50-100 \mathrm{k}$ & .105 & 2.56 & .692 & 1.14 \\
\hline Research income: over $100 \mathrm{k}$ & .115 & 3.83 & -1.48 & -2.03 \\
\hline Teaching score & .039 & 3.20 & .070 & 0.35 \\
\hline Workplace characteristics & & & & \\
\hline RAE 5* & -.000 & -0.01 & .251 & 0.39 \\
\hline RAE 5 & .017 & 0.62 & 1.12 & 2.58 \\
\hline RAE 4 & & & & \\
\hline RAE 3 & -.004 & -0.14 & -.146 & -0.27 \\
\hline RAE 2 & -.000 & 0.00 & -.924 & -0.97 \\
\hline RAE 1 & -.067 & -1.47 & & \\
\hline RAE N/A & -.007 & -0.08 & & \\
\hline Old university & -.023 & -0.67 & -.382 & -0.75 \\
\hline London & .046 & 1.58 & -.241 & -0.50 \\
\hline London 5* & .243 & 4.00 & .846 & 1.00 \\
\hline Other England & & & & \\
\hline Wales/N. Ireland & -.025 & -0.52 & .399 & 0.44 \\
\hline Scotland & .019 & 0.59 & .041 & 0.07 \\
\hline Labour Market Experience & & & & \\
\hline External & .005 & 0.27 & 1.15 & 3.26 \\
\hline Career break & -.005 & -1.11 & .015 & 0.12 \\
\hline Non-academic experience & .001 & 0.89 & .020 & 0.55 \\
\hline Fixed-term Contract & -.165 & -4.68 & & \\
\hline Sample size & 351 & & 316 & \\
\hline Adjusted R-squared & 0.65 & & $0.55(\mathrm{ps}$ & lo R-sq) \\
\hline
\end{tabular}


TABLE 6: The Determinants of Earnings by Gender - Academics Aged 35+

\begin{tabular}{|c|c|c|c|c|c|c|c|c|}
\hline \multirow{4}{*}{$\begin{array}{l}\text { Variables } \\
\text { Estimation Method and } \\
\text { Dependent Variable } \\
\text { Constant }\end{array}$} & \multicolumn{3}{|c|}{$\mathbf{i}$} & \multicolumn{3}{|c|}{ ii } & \multicolumn{2}{|c|}{ iii } \\
\hline & Coeff & t-stat & F-test & Coeff & t-stat & F-test & Coeff & z-stat \\
\hline & \multicolumn{3}{|c|}{ OLS Log Earnings } & \multicolumn{3}{|c|}{ OLS Log Earnings } & \multicolumn{2}{|c|}{$\begin{array}{l}\text { Ordered Probit } \\
\text { Offers }\end{array}$} \\
\hline & \\
\hline \multicolumn{9}{|l|}{ White } \\
\hline Black/Asian & -.118 & -2.14 & & -.086 & -2.17 & & -.326 & -0.77 \\
\hline Other ethnic & -.036 & -0.57 & & .005 & 0.11 & & .045 & 0.10 \\
\hline Male & .073 & 0.47 & & .063 & 0.55 & & .523 & 2.00 \\
\hline Male married & .034 & 1.01 & 0.93 & .018 & 0.76 & 1.44 & .096 & 0.43 \\
\hline Female married & .110 & 1.57 & $(0.33)$ & .086 & 1.70 & $(0.23)$ & & \\
\hline Age & .035 & 1.83 & & .006 & 0.47 & & .226 & 1.55 \\
\hline Age squared x 10 & -.002 & -1.14 & & -.000 & -0.03 & & -.026 & -1.76 \\
\hline \multicolumn{9}{|l|}{ Productivity } \\
\hline Degree: UK first class & .044 & 1.57 & & -.012 & -0.61 & & -.044 & -0.22 \\
\hline \multicolumn{9}{|l|}{ Degree: UK upper second } \\
\hline Degree: other UK & -.059 & -1.49 & & -.051 & -1.77 & & -.356 & -1.14 \\
\hline Degree: overseas & .028 & 0.75 & & .000 & 0.00 & & .323 & 1.28 \\
\hline $\mathrm{PhD}$ & .021 & 0.77 & & -.014 & -0.68 & & -.341 & -1.71 \\
\hline Male publications score $\mathrm{x} 10$ & .020 & 3.94 & 0.98 & .004 & 1.56 & 2.17 & .004 & 0.15 \\
\hline $\begin{array}{l}\text { Female publications score x } 10 \\
\text { Research income: none }\end{array}$ & .030 & 3.03 & $(0.32)$ & .016 & 2.17 & $(0.14)$ & & \\
\hline Research income: up to $50 \mathrm{k}$ & -.020 & -0.73 & & -.017 & -0.85 & & .058 & 0.28 \\
\hline Male res. income: $50-100 \mathrm{k}$ & .055 & 0.98 & 0.45 & -.032 & -0.78 & 0.72 & .254 & 0.76 \\
\hline Female res. income: $50-100 \mathrm{k}$ & .126 & 1.38 & $(0.50)$ & .032 & 0.48 & $(0.39)$ & & \\
\hline Male res. income: over $100 \mathrm{k}$ & .029 & 0.48 & 0.00 & .059 & 1.35 & 0.92 & .392 & 1.72 \\
\hline Female res. income: over $100 \mathrm{k}$ & .025 & 0.28 & $(0.97)$ & -.007 & -0.11 & $(0.39)$ & & \\
\hline Male teaching score & .027 & 1.72 & 1.29 & .025 & 2.21 & 2.15 & .007 & 0.06 \\
\hline Female teaching score & .076 & 1.92 & $(0.25)$ & .071 & 2.46 & $(0.14)$ & & \\
\hline \multicolumn{9}{|l|}{ Workplace characteristics } \\
\hline London & .040 & 1.07 & & .035 & 1.31 & & .550 & 2.00 \\
\hline London 5* & .307 & 3.79 & & .246 & 4.24 & & -.071 & -0.13 \\
\hline \multicolumn{9}{|l|}{ Labour Market Experience } \\
\hline External & -.009 & -0.37 & & .012 & 0.65 & & .345 & 2.03 \\
\hline Career break & -.004 & -0.91 & & .001 & 0.31 & & -.103 & -2.06 \\
\hline Non-academic experience & .000 & 0.45 & & -.001 & -0.77 & & .007 & 0.49 \\
\hline Male outside offers & .060 & 3.94 & 8.48 & .029 & 2.62 & 12.20 & & \\
\hline Female outside offers & -.089 & -1.80 & $(0.00)$ & -.101 & -2.82 & $(0.00)$ & & \\
\hline \multicolumn{9}{|l|}{ Rank } \\
\hline Professor & & & & .374 & 6.49 & & & \\
\hline Reader/Senior Lecturer & & & & .133 & 2.33 & & & \\
\hline Lecturer & & & & .021 & 0.39 & & & \\
\hline Temporary Lecturer & & & & -.072 & -0.93 & & & \\
\hline Research Officer & & & & & & & & \\
\hline Sample size & 262 & & & 262 & & & 262 & \\
\hline Adjusted R-squared & 0.48 & & & 0.73 & & & 0.12( & eudo) \\
\hline
\end{tabular}

Notes: The F-test compares the male and female coefficients, with the bracketed figure the probability that the two are equal. RAE scores, old university, and region other than London are estimated but not reported. 
TABLE 7: Publications, Perceived Discrimination and Applications

\begin{tabular}{|c|c|c|c|c|c|c|}
\hline \multirow{3}{*}{$\begin{array}{l}\text { Estimation Method and } \\
\text { Dependent Variable } \\
\text { Variables } \\
\text { Constant } \\
\text { Individual characteristics }\end{array}$} & \multicolumn{2}{|c|}{$\begin{array}{c}\mathbf{i} \\
\text { Tobit Publications } \\
\text { Score }\end{array}$} & \multicolumn{2}{|c|}{$\begin{array}{c}\text { ii } \\
\text { Probit Perceived } \\
\text { Discrimination }\end{array}$} & \multicolumn{2}{|c|}{$\begin{array}{c}\text { iii } \\
\text { Ordered Probit } \\
\text { Applications }\end{array}$} \\
\hline & Coeff & t-stat & Coeff & z-stat & Coeff & z-stat \\
\hline & -162.171 & -3.51 & .424 & 0.19 & & \\
\hline \multicolumn{7}{|l|}{ White } \\
\hline Black/Asian & -6.764 & -0.75 & .365 & 1.01 & -.188 & -0.47 \\
\hline Other ethnic & -3.721 & -0.31 & .085 & 0.18 & -.434 & -0.95 \\
\hline Male & 15.871 & 2.57 & -.700 & -2.87 & .374 & 1.40 \\
\hline Married & 2.761 & 0.51 & -.312 & -1.32 & -.221 & -1.02 \\
\hline Age & 5.965 & 2.79 & -.061 & -0.61 & -.028 & -0.19 \\
\hline Age squared x 10 & -.060 & -2.55 & .008 & 0.78 & -.004 & -0.26 \\
\hline \multicolumn{7}{|l|}{ Productivity } \\
\hline $\begin{array}{l}\text { Degree: UK first class } \\
\text { Degree: UK upper second }\end{array}$ & 9.251 & 1.73 & -.131 & -0.48 & -.132 & -0.62 \\
\hline Degree: other UK & -6.657 & -0.77 & -.039 & -0.10 & .298 & 1.09 \\
\hline Degree: overseas & 6.929 & 1.05 & .634 & 2.30 & .703 & 2.59 \\
\hline $\mathrm{PhD}$ & 6.135 & 1.06 & -.015 & -0.05 & .332 & 1.61 \\
\hline $\begin{array}{l}\text { Publications score x } 10 \\
\text { Research income: none }\end{array}$ & & & .028 & 0.79 & .029 & 1.07 \\
\hline Research income: up to $50 \mathrm{k}$ & 6.953 & 1.30 & .780 & 3.37 & .121 & 0.59 \\
\hline Research income: $50-100 \mathrm{k}$ & 16.176 & 1.72 & .336 & 0.81 & .254 & 0.74 \\
\hline Research income: over $100 \mathrm{k}$ & 20.109 & 3.01 & -.127 & -0.34 & -.048 & -0.19 \\
\hline Teaching score & .921 & 0.32 & .033 & 0.24 & -.021 & -0.19 \\
\hline \multicolumn{7}{|l|}{ Workplace characteristics } \\
\hline RAE 5* & 2.991 & 0.26 & -.468 & -0.79 & -1.520 & -2.62 \\
\hline RAE 5 & 13.328 & 2.12 & .249 & 0.85 & -.566 & -2.33 \\
\hline \multicolumn{7}{|l|}{ RAE 4} \\
\hline RAE 3 & 4.680 & 0.64 & -.120 & -0.35 & -1.835 & -0.68 \\
\hline RAE 2 & -8.520 & -0.75 & -.046 & -0.10 & -.152 & -0.39 \\
\hline RAE 1 & -11.591 & -1.04 & -.581 & -1.26 & -.517 & -1.38 \\
\hline RAE N/A & -17.390 & -0.67 & -.167 & -0.20 & -1.08 & -1.40 \\
\hline Old university & 13.827 & 1.758 & -.847 & -2.55 & -.344 & -1.21 \\
\hline London & -3.342 & -0.47 & .114 & 0.41 & -.656 & -2.43 \\
\hline London 5* & 16.882 & 1.19 & -.646 & -0.82 & .535 & 0.79 \\
\hline \multicolumn{7}{|l|}{ Other England } \\
\hline Wales/N. Ireland & 13.242 & 1.22 & .288 & 0.60 & -.234 & -0.62 \\
\hline Scotland & 2.433 & 0.31 & .022 & 0.06 & -.252 & -0.87 \\
\hline \multicolumn{7}{|l|}{ Labour Market Experience } \\
\hline External & -5.656 & -1.18 & .014 & 0.06 & .350 & 1.99 \\
\hline Career break & 1.081 & 0.96 & .005 & 0.11 & -.020 & -0.48 \\
\hline Non-academic experience & -.647 & -1.55 & .007 & 0.45 & -.036 & -2.56 \\
\hline \multicolumn{7}{|l|}{ Unexplained Earnings } \\
\hline Male & & & -1.03 & -1.45 & .667 & 1.28 \\
\hline Female & & & -2.76 & -1.89 & -3.384 & -2.11 \\
\hline
\end{tabular}


Sample size

351

0.03

347

0.21

260

Adjusted R-squared

(pseudo)

(pseudo) 